\title{
CHANGES IN THE EFFICACY OF FUNGICIDAL CONTROL OF ONION WHITE ROT
}

\author{
J.L. TYSON ${ }^{1}$, R.A. FULLERTON ${ }^{1}$ and A. STEWART ${ }^{2}$ \\ ${ }^{1}$ HortResearch, Private Bag 92169, Auckland \\ ${ }^{2}$ Soil, Plant and Ecological Sciences Division, P.O. Box 84, \\ Lincoln University, Canterbury, New Zealand
}

\begin{abstract}
Disease incidence data from field trials on the control of onion white rot (Sclerotium cepivorum Berk.) in the Pukekohe district of New Zealand over the period 1979-99 were reviewed. It was shown that the efficacy of the fungicides iprodione, procymidone, tebuconazole and triadimenol varied greatly from year to year. There was no relationship between efficacy and a range of agronomic and environmental factors, and the variations were most likely to be the result of changes in soil conditions that affected the persistence or activity of the fungicides in the soil. The commercial experience of unpredictable performance of the fungicides from year to year was confirmed.

Keywords: Sclerotium cepivorum, onion white rot, fungicides, control, efficacy.
\end{abstract}

\section{INTRODUCTION}

The soil-borne disease, onion white rot, caused by Sclerotium cepivorum Berk., is one of the most destructive and insidious diseases of onion crops worldwide. The disease is present on most farms in the Pukekohe district of New Zealand and is considered a major threat to the viability of onion production in the district (Webber et al. 1999).

The use of fungicides for the control of onion white rot is now essential for the economic production of onions on most properties. Current fungicide recommendations (Anon. 1998) involve seed treatment with either Rovral WP (iprodione $500 \mathrm{~g} / \mathrm{kg}$ ) or Sumisclex WP (procymidone $500 \mathrm{~g} / \mathrm{kg}$ ), followed by either Sumisclex Granules (procymidone $100 \mathrm{~g} / \mathrm{kg}$ ), applied to the soil above the seed row at planting, or Sumisclex 25 (procymidone $250 \mathrm{~g} / \mathrm{kg}$ ), Folicur 430SC (tebuconazole $430 \mathrm{~g} / \mathrm{litre}$ ), or Cereous (triadimenol $250 \mathrm{~g} / \mathrm{litre}$ ), applied 3-4 times at monthly intervals, commencing at 6-8 weeks after planting.

Procymidone and tebuconazole have been the mainstay of white rot control for the past 10 years. However, in recent years instances have occurred where these fungicides have not provided the expected degree of control. This study reviews the results of field trials carried out from 1979-1999 in order to evaluate the relative performance of the different fungicides over that time.

\section{METHODS}

Disease incidence data were obtained from published papers and commercial reports of 11 trials over the period 1979-1999. Data were extracted only for treatments in which foliar applications of the fungicides were used at the recommended commercial rates, and the respective untreated controls. The fungicides evaluated were iprodione at $0.75 \mathrm{~kg} / \mathrm{ha}$ (as Rovral WP), procymidone at $0.75 \mathrm{~kg} / \mathrm{ha}$ (as Sumisclex 25), tebuconazole at $0.375 \mathrm{~kg} / \mathrm{ha}$ (as Folicur $430 \mathrm{SC}$ or $250 \mathrm{EC}$ ) and triadimenol at $0.375 \mathrm{~kg}$ / ha (as Cereous).

All trials were carried out on grower properties, often within commercial onion fields (Table 1). 
TABLE 1: Dates of planting and initial fungicide application in trials over the period 1979-99.

\begin{tabular}{llllll}
\hline Year & $\begin{array}{l}\text { Planting } \\
\text { date }\end{array}$ & $\begin{array}{l}\text { Initial } \\
\text { fungicide } \\
\text { application }\end{array}$ & Year & $\begin{array}{l}\text { Planting } \\
\text { date }\end{array}$ & $\begin{array}{l}\text { Initial } \\
\text { fungicide } \\
\text { application }\end{array}$ \\
\hline $1979-80$ & 29 May & 7 September & 1991-92 & 13 June & 14 August \\
$1984-85$ & 27 June & 22 August & 1992-93 & 3 June & 24 August \\
$1985-86$ & 7 August & 4 September & $1996-97$ & 18 June & 6 September \\
$1986-87$ & 3 July & 14 August & $1997-98$ & 15 June & 17 July \\
$1987-88$ & 15 July & 19 August & $1998-99$ & 6 July & 14 August \\
$1989-90$ & 28 June & 24 August & & & \\
\hline
\end{tabular}

The existence of treatment/location interactions (i.e. differing disease pressure) made direct comparisons of mean percentages of disease difficult. Relative fungicide efficacy for each treatment in each trial was therefore calculated as:

$100 \times$ ( $1-\%$ disease in the fungicide treatment / \% disease in the untreated control).

The historical data available did not lend itself to strict statistical analysis. Nevertheless, in order to explain variations in fungicide performance, possible relationships between efficacy and a range of agronomic and environmental factors were investigated. These included planting date, time of initial fungicide application and disease severity in the trial site (\% diseased plants in the untreated controls). Relationships between average monthly soil temperatures $(10 \mathrm{~cm})$ and monthly rainfall in July, August, September, October, November and total rainfall over those months were also examined.

\section{RESULTS}

The relative efficacy of the fungicides at different times over the 20 year period are shown in Fig. 1.

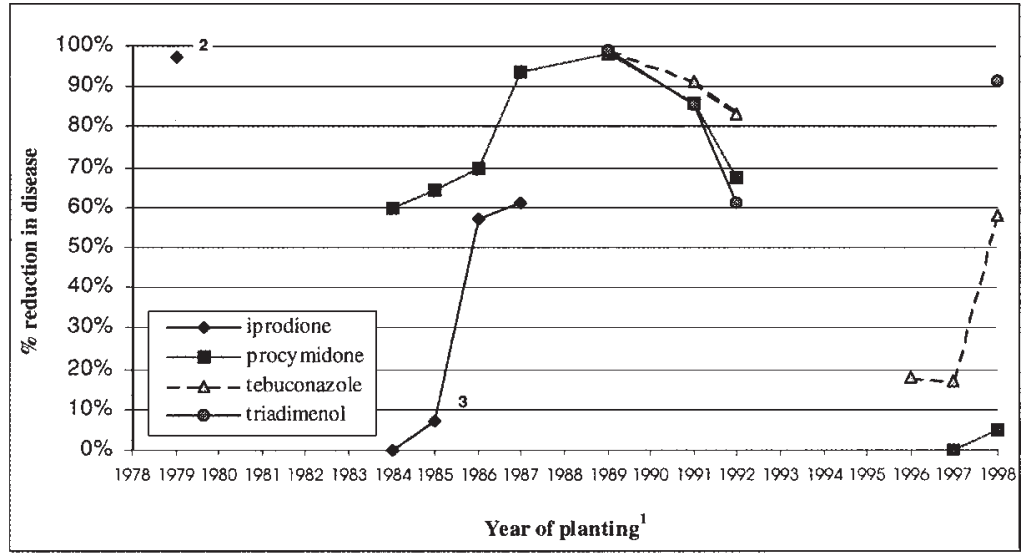

${ }^{1}$ Dates shown are year of planting; e.g. 1984 refers to the $1984-85$ crop year

${ }^{2} 1979$ efficacy data for iprodione obtained from Wood (1980)

${ }^{3}$ Where data were available for successive years, points are joined up to help identify the fungicides and illustrate the trends.

FIGURE 1: Percentage reduction in disease in onions treated with iprodione, procymidone, tebuconazole and triadimenol over the period 1979-99. 
The efficacy of all fungicides varied substantially over time. In the field trial of 1979-80, iprodione achieved almost $100 \%$ reduction in disease. However, in field trials in both 1984 and 1985, its efficacy was less than 10\%. In subsequent trials in 1986 and 1987 the efficacy was approximately $60 \%$.

In the 1984-85 growing season, procymidone achieved a $60 \%$ reduction in disease. In subsequent years, efficacy increased with a $98 \%$ reduction in disease being obtained in the 1989-90 season. Subsequently, there was a progressive reduction in efficacy with no control being obtained in the 1997-98 and 1998-99 seasons.

In the 1989-90 season tebuconazole and triadimenol achieved approximately $99 \%$ reduction in disease. Thereafter there was a progressive decline in efficacy of both fungicides. The efficacy of tebuconazole was only $18 \%$ and $17 \%$ in the $1996-97$ and 1997-98 seasons respectively. In the most recent trial (1998-99 season), tebuconazole achieved a 58\% reduction in disease and triadimenol, which had not been evaluated in trials since 1992-93, achieved a $92 \%$ reduction in disease.

No correlation was found between fungicide efficacy and either planting date or the timing of the initial fungicide application. There was no correlation between fungicide efficacy and disease incidence in the untreated controls (Fig. 2).

Fungicide efficacy was not directly related to either rainfall or soil temperature for any of the data sets studied. A typical example of the variable pattern of response obtained is shown in Fig. 3. Whilst October rainfall was similar in 1992, 1997 and 1998 , the efficacy of tebuconazole in those years was $83.3 \%, 16.9 \%$ and $58.1 \%$ respectively. Average October soil temperatures were comparable in 1991 and 1997, whilst the efficacy of tebuconazole was $91.6 \%$ and $16.9 \%$ respectively. Similar inconsistencies were found with all monthly temperature and rainfall data examined.

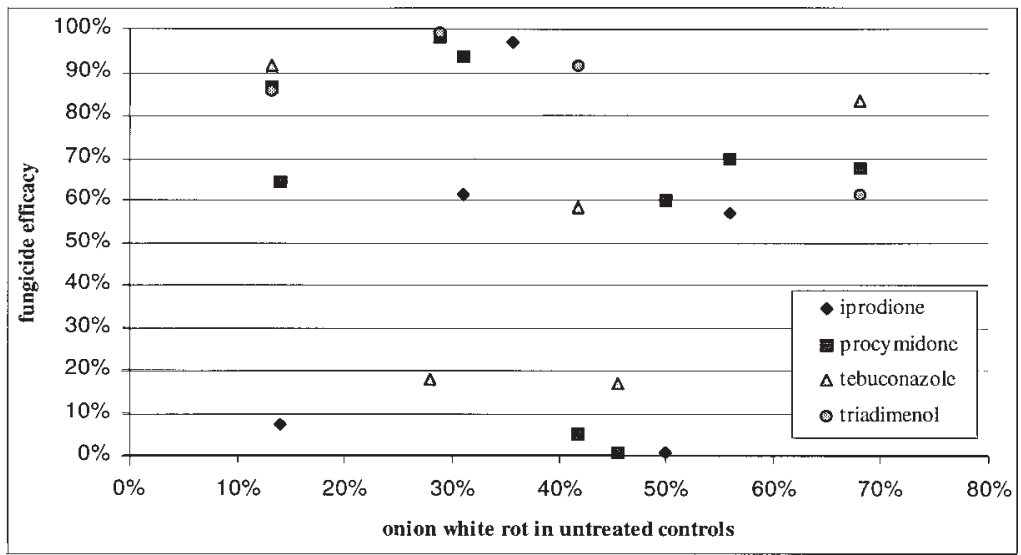

FIGURE 2: Relative efficacy of iprodione, procymidone, tebuconazole and triadimenol compared with disease severity in untreated controls over the period 1978-99.

\section{DISCUSSION}

There have been large variations in the efficacy of the fungicides examined over time. In general, the direction of change over any particular period was similar for all the fungicides being evaluated. The declining efficacy noted in trials over the period 1989-97 correlated with the apparent loss of efficacy of procymidone and tebuconazole in commercial crops throughout the district over the same period.

The loss of efficacy by iprodione in 1984 has been attributed to enhanced microbial degradation of the fungicide in the soil (Walker 1987; Slade et al. 1992). 


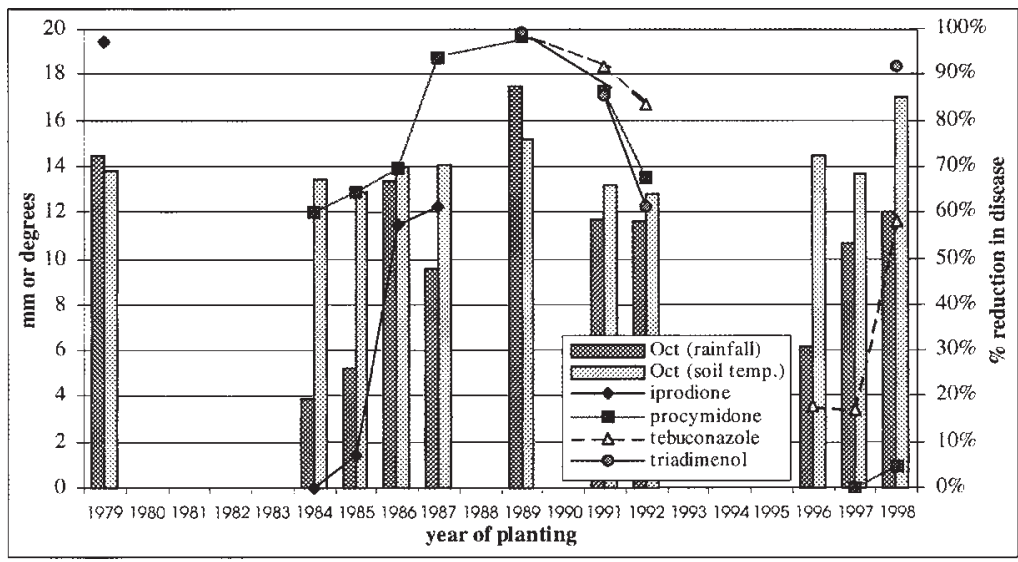

FIGURE 3: Fungicide efficacy compared with October rainfall and soil temperatures over the period 1979-98.

However, the efficacy of iprodione was substantially greater in trials during 1986-88 than in 1984. It is possible that site-specific differences in rate of degradation were responsible for some of the variations in efficacy. Slade et al. (1992) showed that procymidone was not subject to enhanced degradation in Pukekohe soils and in a recent study no evidence of enhanced degradation of procymidone in test soils was found (G. Brown, pers. comm.). Enhanced degradation is not considered to influence efficacy of procymidone, tebuconazole or triadimenol.

More than 150 strains of S. cepivorum isolated from the Pukekohe district have been evaluated for resistance to procymidone (Cropcare Holdings Ltd, unpublished data) and tebuconazole (J. Tyson and R. Fullerton, unpublished data) in laboratory tests. There is no evidence to suggest increased pathogen tolerance to either of these fungicides.

There was no relationship between the efficacy of the fungicides and disease incidence in the untreated controls. In the 1997-98 and 1998-99 trials, tebuconazole achieved $<20 \%$ and approximately $60 \%$ control respectively in immediately adjacent sites with similar disease incidence in the controls. Location did not appear to affect the efficacy of either procymidone or tebuconazole.

Fungicide efficacy was not related to either planting date or timing of the initial fungicide application. This is supported by the results from the 1997-98 season in which the fungicides were used in early-planted (15 June) and late-planted (17 July) trials on immediately adjacent sites. There were no significant differences between trials in final disease incidence, the timing of the epidemic (i.e. the period of maximum rate of disease development), or the efficacy of the fungicides used in the trials (unpublished data, courtesy of the New Zealand Onion Exporters Association).

The timing of fungicide applications in relation to the onset of the disease epidemic could possibly influence the control achieved. However, the quality of the historical data available was not adequate to examine this factor in detail.

Annual variations in the success of fungicidal control of plant diseases are common in both foliar and soil-borne diseases. Gaudet et al. (1989) found that variations in the efficacy of some fungicides used to control common bunt of wheat (Tilletia caries (DC.) Tul. and T. foetida (Wallr.) Liro.) were the result of variations in temperature and moisture. The present review suggests that variations in efficacy of fungicides in controlling onion white rot are more likely to be the result of changes in soil conditions that affect the persistence or activity of the fungicides in the soil, than to any inherent characteristic of the pathogen. Although this review did not show the 
specific cause of variation in efficacy, soil temperature, soil moisture and rainfall, and their interactions, remain the most likely contributing factors.

This study confirms grower observations that the success of fungicidal control of white rot can vary greatly between seasons. Furthermore, these variations can occur independently of the background incidence of the disease. The variable and unpredictable performance of the fungicides introduces a further element of risk into onion production in areas heavily infested with white rot.

\section{ACKNOWLEDGEMENTS}

The authors would like to thank Bayer New Zealand Ltd, the New Zealand Onion Exporters Association, and Cropcare Holdings Ltd for allowing data in commercial reports to be used for this study, and the many growers who assisted with the trials over many years.

\section{REFERENCES}

Anon., 1998. New Zealand Agrichemical Manual: 1998/99 update. WHAM Chemsafe Ltd, Wellington, New Zealand.

Webber, D., Buchan, D.J., Cosslet, C.B., Santorum, A., Wood, R.J. and Fullerton, R.A., 1999. High Stakes in Pukekohe. An economic and social assessment of the onion industry with special reference to the impact of onion white rot disease in the Pukekohe area. HortResearch Technical Report No. 1999/224. 56p.

Gaudet, D.A., Puchalski, B.J. and Entz T., 1989. Effect of environment on efficacy of seed-treatment fungicides for the control of common bunt in spring and winter wheat. Pesticide Sci. 26: 241-252.

Slade, E.A., Fullerton, R.A., Stewart, A. and Young, H., 1992. Degradation of the dicarboximide fungicides iprodione, vinclozolin and procymidone in Patumahoe clay loam soil in New Zealand. Pesticide Sci. 35: 95-100.

Walker, A., 1987. Further observations on the enhanced degradation of iprodione and vinclozolin in soil. Pesticide Sci. 21(3): 219-231.

Wood, R.J., 1980. Control of onion white rot with iprodione.Proc. $33^{\text {rd }}$ N.Z. Weed and Pest Control Conf.: 203-205. 